\title{
Reversibility of the effects of natalizumab on peripheral immune cell dynamics in MS patients
}

Neurology ${ }^{\circledR}$ 2020;95:661. doi:10.1212/WNL.0000000000008927

In the article "Reversibility of the effects of natalizumab on peripheral immune cell dynamics in MS patients" by Plavina et al., there is an error in the "Monocyte/VCAM-1 binding" key of figure 3. "Natalizumab continued" should have been represented by a green line and gray square; "Natalizumab interrupted" should have been represented by a red line and black circle. The editorial office regrets the errors.

Figure 3 Functional activity of CD3+ T cells, CD19+ B cells, and monocytes from RESTORE patients

\section{CD3+/VCAM-1 binding}

Natalizumab continued

$\multimap$ Natalizumab interrupted

\section{CD19+/VCAM-1 binding}

$-\square-$ Natalizumab continued

- - Natalizumab interrupted
Monocyte/VCAM-1 binding

$\rightarrow-$ Natalizumab continued

- - Natalizumab interrupted

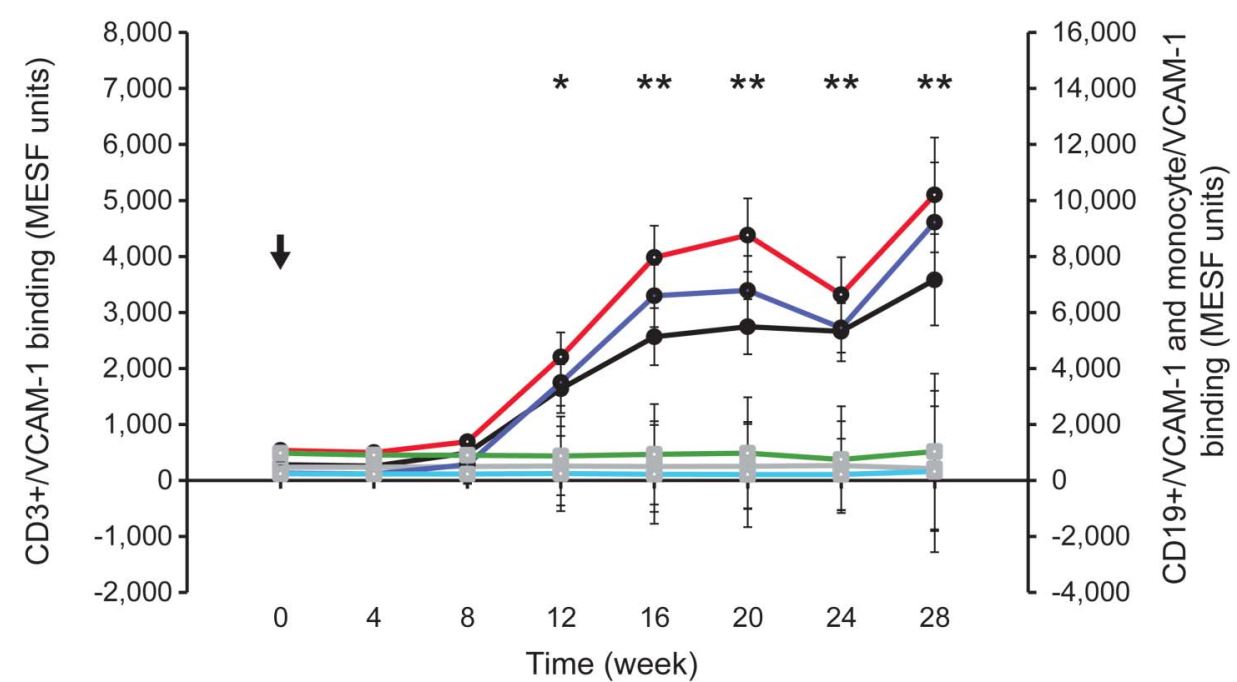

Number of patients evaluated:

$\begin{array}{lrrrrrrrr}\text { Continued } & 42 & 40 & 39 & 39 & 38 & 42 & 40 & 38 \\ \text { Discontinued } & 109 & 111 & 113 & 102 & 94 & 94 & 77 & 63\end{array}$

\section{Reference}

1. Plavina T, Muralidharan KK, Kuesters G, et al. Reversibility of the effects of natalizumab on peripheral immune cell dynamics in MS patients. Neurology 2017;89:1584-1593. 


\title{
Neurology
}

\section{Reversibility of the effects of natalizumab on peripheral immune cell dynamics in MS patients}

Neurology 2020;95;661 Published Online before print September 16, 2020

DOI 10.1212/WNL.0000000000008927

This information is current as of September 16, 2020

\author{
Updated Information \& \\ Services \\ including high resolution figures, can be found at: \\ http://n.neurology.org/content/95/14/661.full \\ References \\ This article cites 1 articles, 1 of which you can access for free at: \\ http://n.neurology.org/content/95/14/661.full\#ref-list-1 \\ Permissions \& Licensing \\ Information about reproducing this article in parts (figures,tables) or in \\ its entirety can be found online at: \\ http://www.neurology.org/about/about_the_journal\#permissions \\ Reprints \\ Information about ordering reprints can be found online: \\ http://n.neurology.org/subscribers/advertise
}

Neurology ${ }^{\circledR}$ is the official journal of the American Academy of Neurology. Published continuously since 1951, it is now a weekly with 48 issues per year. Copyright (C 2020 American Academy of Neurology. All rights reserved. Print ISSN: 0028-3878. Online ISSN: 1526-632X.

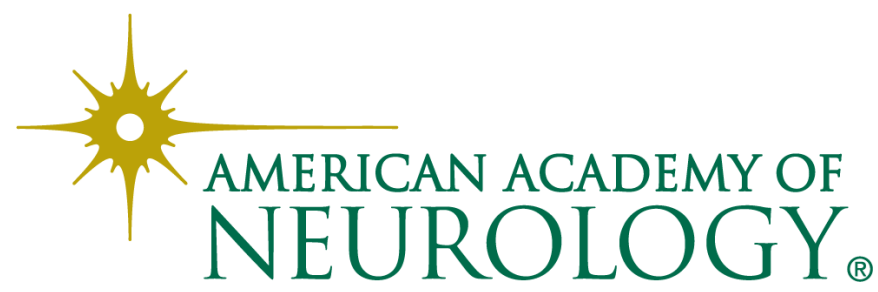

